\title{
Language Intervention at Schools: Changing Orientations within the South African context
}

\author{
Erna Alant, D Phil (Pretoria) \\ Department of Speech Pathology and Audiology, \\ University of Pretoria
}

\begin{abstract}
The role of the speech therapist in the school has changed drastically over the last decade. The reasons for these changesoriginate from a growing realisation of the importance of contextualising intervention within a particular community.

This article aims at providing an analysis of the present school population in South Africa with specific reference to the Blackschools as a basis for discussion on the role of the speech and language therapist within this context.

The problems of second language learning and teaching are highlighted and the role of the language therapist as a consultant within the Black school system is emphasized.
\end{abstract}

\section{OPSOMMING}

Die rol van die spraak-en taalterapeut binne die skoolkonteks het die afgelope dekade drastiese veranderinge ondergaan. Die redes vir hierdie veranderinge spruit uit 'n groeiende bewuswording van die belangrikheid van die kontekstualisering van intervensie binne 'n bepaalde gemeenskap.

Hierdie artikel poogom 'n analise te maak van die huidige skoolbevolking van Suid-Afrika met spesifieke verwysing na die swart skole as basis vir bespreking van die rol van die spraak-en taalterapeut binne hierdie konteks.

Die probleme van tweedetaalonderrig en -leer asook die rol van die taalterapeut as konsultant binne die swart skoolsisteem word beklemtoon.

The role of the speech and language therapist in language remediation has changed drastically over the last decade. These changes are evident in diagnostic and therapeutic intervention and can be seen as, an outcome of the paradigm shift from a traditional medical model of service where the therapist was mainly involved in individual therapy, to a functional or consultative model where the therapist is more involved in the facilitation of the individual's communication within specific functional contexts (Marvin, 1987). The new pragmatic approach (Gallagher et al. 1983) with the strong emphasis on the functionality of language and interaction has forced the therapist to move out of the therapy room and into the classroom or every day environment, as the following quotation illustrates: "We cannot expect to be employed by a school if we only provide limited services within a medical model." (Simon, 1987:41.)

Apart from a new theoretical or philosophical orientation, focus on the functionality of language brought with it many more issues that confront the language pathologist. For example, if the aim of language intervention is to improve general communicative competence by alleviating language patho$\log y$, what exactly is meant by communicative competence and language pathology?

Firstly, the therapist has to consider the dynamic nature of the concept of 'communicative competence'. A functional orientation towards therapy implies that the therapist has to consider the social context within which individuals interact. She has to be aware of the use of language in different contexts in order to plan relevant intervention goals. Being aware of the norms of the broader society (or ruling class) as well as the immediate environment of the individual therefore forms the basis of intervention. The therapist can work in a variety of contexts (daily living, the home and work environment, or the academic context), which pressupposes a thorough understanding of communication skills required within these contexts. Effective intervention thus necessitates a sound understanding of the interrelationship between the individual and the society, and the specific contexts within which he functions. Only by acknowledging the dynamic nature of society can the concept of communication competence be operationalized.

Secondly, much emphasis has been placed on sensitising therapists to the difference between language pathology (deviance) and language difference within varied linguistic contexts in order to prevent misdiagnosis of language pathology. Once again, this implies an active understanding of the linguistic contexts within which nonstandard language variations are used, the cultural implications as well as the problems involved in communicating within the broader societal context. Therapists have to be sensitized to work with both bidialectical and bilingual language situations in an attempt not only to diagnose, but also to plan effective and relevant intervention.

Although basic to the work of the language pathologist, the issue of what constitutes communicative competence and pathology remains complex and difficult to deal with, especially within the South African context. This article aims to describe some of the broader communication needs within the educational system in South Africa in order to facilitate the restruc- 
turing and reformulation of the role of the language therapist within this context.

One of the major difficulties confronting any profession is the need for continuous adaptation of training in order to ensure the creation of relevant skills in the context of a changing society (Adler, 1988; Uys, 1985). It is theretore difficult to describe the role of the speech and language pathologist without some reference to the context within which these professionals have to function.

One of the more controversial issues in the American literature in the last decade, has been the involvement of the speech and language therapist in dealing with children who speak nonstandard languages. This problem did not only lead to much critical evaluation and discussion on the effectiveness of evaluation and therapeutic procedures (Taylor, 1986; VaughnCooke, 1986), but also highlighted the language needs of these children. In this regard, ASHA (1983) stated that "Speechlanguage pathologists may also be available to provide elective clinical service to nonstandard language speakers who do not present a disorder." Sol Adler (1985), however, describes the approach taken by ASHA as a "do nothing" or laissez-faire strategy that is totally unacceptable as he believes that the therapist should be involved in the facilitation of bidialectism within the school context. The urgency of this appeal stems from the many research studies (Edwards, 1979; Taylor, 1986) which confirm the disadvantaged position of these children when entering the school context. This disadvantage also extends to the employment situation when the children are not able to familiarize themselves adequately with the standard language used within a particular society (Edwards, 1979; Terrell et al. 1983).

An equally important assertion by Adler (1985) in answer to the position paper of ASHA (1983) is that the focus on the linguistic aspects of bidialectism and bilingualism detracts from the importance of a sound cultural understanding when working within any communication context. Many authors stress the interrelationship between communicative competence in language and understanding of the social context within which that language functions, which supports the issues raised by Adler in this regard (e.g. Chick, 1987;' 'rudgill, 1987). To become a bidialectical or bilingual speaker involves much more than learning the rules of a particular language. Various authors (Taylor, 1986; Westby and Rouse, 1985) in the field of bilingual education have stressed the importance of cultural education in an attempt to enhance bilingualism.

For example, the importance of the cultural context in evaluation and remediation is highlighted by Taylor (1986:11) in the following statement "... the study of normal and pathological communication must be couched in cultural terms. To do otherwise is to run the risk of making claims and judgements about the communicative behaviours of a given group of speakers from an inappropriate or, even worse, an ethnocentric set of assumptions and norms."

\section{THE ROLE OF THE SCHOOL THERAPIST WITHIN AN AMERICAN CONTEXT}

It may be useful in attempting to find our bearings in the South African situation to examine the role of the school therapist in the United States.

Sensitivity to the social context within which the child func- tions demands that the role of the therapist has to be dynamic in order to comply with the orientations and pressures experienced within a particular school context (Marvin, 1987). Simon (1987:41) elaborates on this point by stating that "... most change is the result of economic factors. When school districts find they are using $26 \%$ of the budget to service $10 \%$ of the school population, current practices are scrutinized." It is therefore important that the therapist critically evaluates her own role in the school context and improves her accountability by identifying the most pressing needs of the children in the school and developing the most effective methods for reaching the largest number of children.

Recent awareness of the therapist's role in nonstandard language as well as the learning disabled contexts stems from a growing realisation of the important role of language within the learning process. The realisation that many students are not successful learners and that there are obvious differences in how children from different social, ethnic and linguistic backgrounds experience the educational set-up contributed to the "rediscovery" of the role language proficiency plays in the educational process (Damico, 1987:17). At the same time, the unease many educators displayed when the topic of languageacross-the curriculum was discussed highlighted the fact that "Few teachers have the academic background, practical experience and professional freedom to address language-related issues by themselves. Consequently language issues are overlooked and children with language differences suffer a variety of abuses within the educational system." (Damico, 1987:17.)

According to Damico (1987) the most likely professional to confront the concerns, abuses and other language related issues in the school is the speech and language pathologist. He emphasizes that the role of the language therapist should be that of a "language specialist" and she should have the flexibility to interact with students and teachers without being tied to a caseload or schedule. This role would involve that the therapist be available to the rest of the school as a consultant on problems relating to language and its impact on classroom activities, testing procedures, culturally diverse populations and other issues. This consultancy would not only involve discussing individual children with the class teacher, but helping to facilitate the student's mastering of the demands made by the school, particularly with regard to the medium of instruc: tion or standard language. "No matter what activities are targetted, language is the delivery medium of instruction. Un less students understand the language, they will not benefit from the instruction." (Comkowycz et al. 1987.)

To facilitate the interaction of the child in the classroom therefore necessitates a closer look at the cultural context and mother-tongue of the children involved, to ensure that intervention is relevant.

It is against this background that the educational context within which the speech and language therapist has to work within South Africa will be discussed. 'The emphasis in the article is on mainstream education although the same issues apply to the special education context.

\section{THE EDUCATIONAL CONTEXT IN SOUTH AFRICA}

In order to provide some basis from which the speech and language therapist's role in the educational process in South Africa can be evaluated,a description of the school context is 
essential. This will be done by looking at three different aspects:

- A description of all the children at school in South Africa during 1988 according to their race in order to get an overall view of the school population.

- A description of the different languages used by staff and students in the Black Schools in 1987.

- A description of the language used most frequently as the medium of instruction in Black schools in 1987.

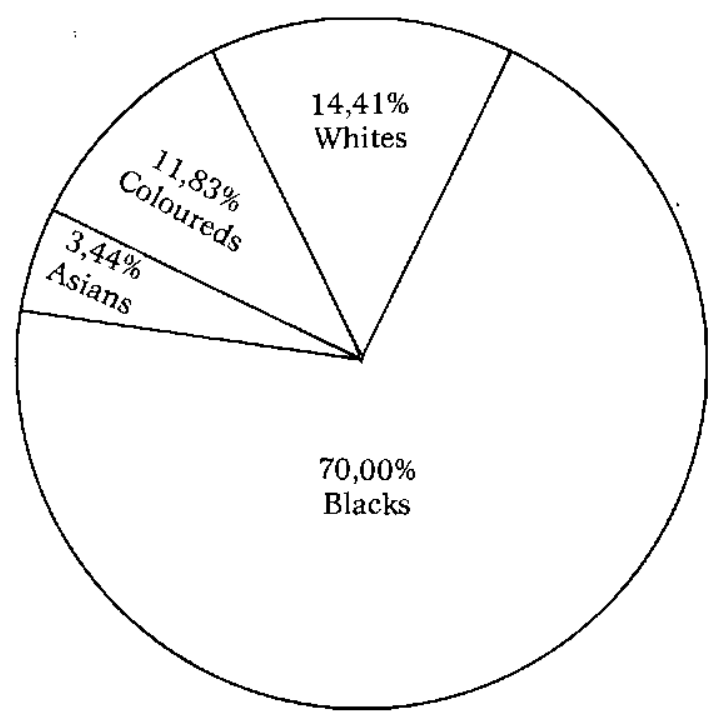

Figure 1: Pupils to population group for 1988 including self-governing states

*Data obtained from Dept of National Education (NATED 02-214)

Table 1: Mother-tongue language used by students and staff in primary schools in DET for 1987 *

\begin{tabular}{|c|c|c|}
\hline LANGUAGE & STUDENTS & STAFF \\
\hline Zúlu & 1395090 & 27675 \\
\hline N Sotho & 649263 & 16633 \\
\hline S Sotho & 386547 & 9503 \\
\hline Xhosa & 365644 & 9459 \\
\hline Tsongo & 286604 & 6485 \\
\hline Tswana & 215869 & 6576 \\
\hline Swazi & 183992 & 4444 \\
\hline S Ndebele & 102683 & 374 \\
\hline $\mathrm{N}$ Ndebele & 33531 & 2091 \\
\hline Venda & 14316 & 328 \\
\hline English/Afrikaans \& Other & - & 124 \\
\hline
\end{tabular}

* Data obtained from DET Annual Report (1987)

From figure 1 it is clear that the majority of the school-going population in South Africa $(70,00 \%)$ is Black, with white children accounting for only $14,41 \%$ of the overall population. This paper will therefore concentrate only on this majority group in order to highlight specific issues.

One of the major issues in the Black school context relates to the different languages used as mother-tongues within this population. Table 1 gives some indication of the number of students speaking a particular mother-tongue.

It is clear from this table that the diversity of languages poses a problem in terms of which language should be used as the medium of instruction within Black schools. The major argu- ments for and against mother-tongue education will not be discussed here, but the reader can consult Reagan (1986) for a summary of the debate. For the purpose of this article it will suffice to quote from the Department of Education and Training's annual report for 1987 in relation to their policy as regards the medium of instruction (DET Annual Report 1987:51.)

"From Substandard A up to the end of Standard 2, the medium of instruction is the pupil's mother-tongue. In Substandard B the teaching of one of the official languages is introduced: that is Afrikaans or English, according to the parent's choice. The teaching of whichever official language was not chosen in Sulstandard B commences in Standard 1. As from Standard 3 the medium of instruction is the mother-tongue or one of the two official languages, as decided by the governing body of the school. Special attention is given to the official language which serves as medium of instruction. Increasingly, the teaching of this language will "cut across the complete curriculum", so that the language becomes an effective medium of instruction. Irrespective of the language being used as the medium of instruction, the mother-tongue and the second official language are offered as subjects."

From this passage, it becomes clear that firstly the second language that will become the medium for instruction of the school is introduced after one year of schooling (Sub B) and is used across the curriculum after three years of exposure to this language. Secondly, the mother-tongue is continued in the form of a subject in the school curriculum. Apart from an acknowledgement and acceptance of the child's home language, this could reflect a sensitivity in the system towards the "interdependency principle" (Kessler, 1984; Mcdonald, 1988) which stresses the importance of the development of the first language for the acquisition of the second language.

From table 1 it is also clear that a very small percentage of teachers in the DET are mother-tongue speakers of English with the majority speaking Zulu as their home language.

Figure 2 provides a clear picture of the languages used as medium of instruction in primary schools.

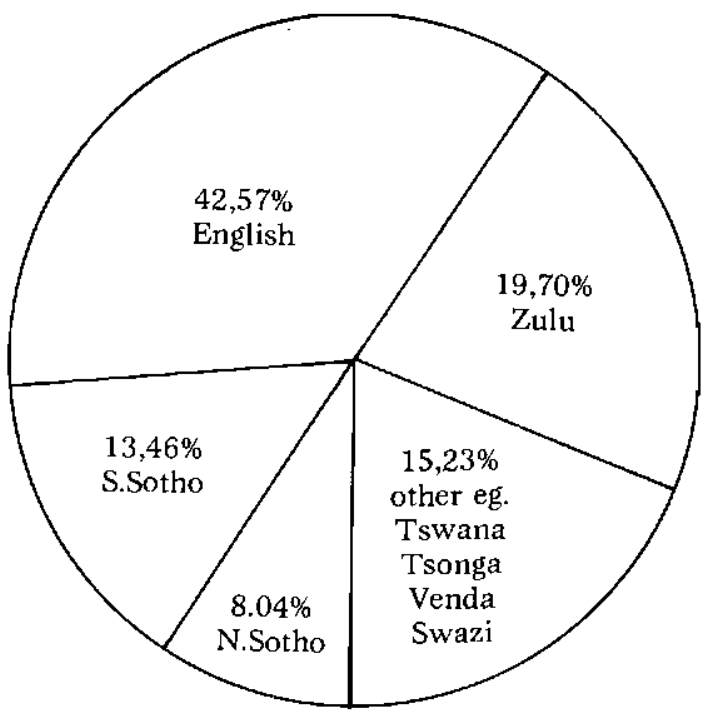

Figure 2: Enrolment according to medium of instruction in primary schools in DET for $1987^{\star}$

* Data obtained from DET Annual Report (1987) 
It is clear that English is the language most commonly used as the medium of instruction, followed by relatively small percentages of a range of other languages. In addition all secondary schools (with only few exceptions) also use English as the medium of instruction.

In this regard, Johanson (1988) states from observation of students at the University of Bophuthatswana that English was widely used, and that only $27 \%$ of student communication recorded took place in the mother-tongue. The mother-tongue was mairily used in communication with parents and elderly people, and in community gatherings, churches and courts. In its pure form, the mother-tongue is very seldom used. Instead mainly a mixture of languages is used in daily interaction. She concludes that English plays an important, but essentially academic role, and is a lingua franca among the educated and sophisticated. "Its importance cannot be questioned, but it is by no means a language of the masses:" (Johanson, 1988:2.) Obviously, any generalization is problematic, but it seems reasonable to conclude that the urban areas would be less mother-tongue orientated than the rural areas.

The implication of these observations is that one can assume a great difference in linguistic background between home and school environments, a factor which contributes to a restricted use of English outside of the academic context. The medium of instruction therefore is (for most of the children) learned and acquired within the school environment, with very little support for the use of English in the actual community (Alant, 1988; Mawasha 1986).

\section{THE ROLE OF THE SPEECH AND LANGUAGE THERA- PIST IN SOUTH AFRICAN SCHOOLS}

A number of important points flow from the above analysis:

- At least $70 \%$ of the total school population (excluding Coloured, Asian and white children speaking a nonstandard language) come from cultural and linguistic contexts which are different from the standard language or prevailing standard English used in South Africa.

- Due to various considerations (Reagan, 1986) it is important for these students to obtain entrance into the standard English or ruling-class cultural context to facilitate the acquisition of communicative competence within the context.

- Teachers at Black schools are mostly teaching in their second language and have limited communicative competency in standard English which not only inhibits and limits teaching, but also causes a high level of frustration.

Various authors have also suggested a strong relationship between the above issues and the generally poor performance of students at school (Odendaal, 1985; HSRC Report 1986). When looking at the overall educational set-up in South Africa it is clear that therapists should be involved within this context of second language teaching particularly as regards the prevention of learning problems at schools. The mere fact that far more than half of the children in schools have to study through a second or third language with only limited support from their own environments accentuates the problems that arise from the language issue within the school context (Lewis, 1988).
Under the circumstances, what should the involvement of the language therapist be? Traditionally the therapist's primary involvement is with the identification and remediation of communication pathology particularly as this pertains to mother-tongue interaction probleres. The underlying philosophy of intervention centers around the individual's basic ability to make contact with people in his immediate environment. Obviously the importance of mother-tongue proficiency cannot be underestimated, particularly also in view of its importance for second dialect or second language learning.

At the same time, the emphasis on functional communication and the acknowledgement that different situations or contexts require different communication skills necessitates that the therapist has a better understanding of the communication demands in specific contexts. The issue centers around the relevance of facilitating communication skills (e.g. mothertongue) in limited contexts only, thus ignoring interactional difficulties and learning problems the individual might encounter in the broader community. This involvement does not, however, imply that the therapist should become a language teacher.

Various writers have expressed the opinion that the therapist is not a teacher and that she can therefore not be held responsible for the actual teaching of a second language (Taylor,1986; Yoder 1970). As therapists have no background in teaching, this argument is valid. Of critical importance to the therapist, however, is the student's competency in the language used as medium ofinstruction in schools, as this is a prime factor in the development of learning problems. In order to prevent as well as remediate language learning problems at school, the therapist has to be involved in the design and planning of language programmes within the school context. To expect the teacher to take full responsibility for the planning of language programmes and the execution of such programmes seems unrealistic, not only because of the complexity of the phenomenon of second language learning, but also because of the teachers' own lack of proficiency in English, the medium of instruction in the majority of schools (Mawasha, 1986). Damico's assertion that the language pathologist seems to be the most appropriate person to confront the concerns, abuses and other language related issues in the school seems relevant in that the language pathologist has the linguistic background and the sensitivity towards communication contexts to support and advise the teacher on strategies and methods that might facilitate language performance (Damico, 1987.)

The therapist's role as language consultant within the school context should therefore be emphasized. She has to aid in the planning and execution of in-service training programmes for teachers and although not responsible for the teaching of a second language, should participate extensively in helping teachers to facilitate interaction in the classroom by demonstrating certain communication skills and strategies. The therapist should therefore be available to teachers as a language specialist as Damico (1987) suggests.

The implication of the above for the training of speech and language therapists within South Africa is self-explánatory. Firstly, students need a firm grounding not only in the development of the mother-tongues, but also in the development of second language skills. Obviously, the emphasis on the development and remediation of the mother-tongue is of prime importance in providing an adequate basis for general interaction skills. The fact that over 70 per cent of children in South 
Africa study by means of a second language negates the possibility that therapists can regard training in second language acquisition and skills as an 'elective' (ASHA 1983).

The training of speech and language therapists in South Africa has been closely linked to the American model. However, in the last decade, particularly with the stress on community work (Aron, 1987) and consultation (Uys, 1985) there have been definite attempts at contextualizing the profession in order to increase its relevance to developing countries. These attempts can only be welcomed, as they reflect a dynamic movement which is vital in the growth process of any profession. Only by on-going self-evaluation and discussion can the "elitism" which often characterizes professions in developing countries be reduced in order to become more relevant to the people most in need of intervention.

\section{REFERENCES}

Adler, S. Comment on social dialects. ASHA, 27, 4, 46-47, 1985.

Adler, S. A new job description and a new task for the public school clinician. LSHSS, 19, 1, 28-33, 1988.

Alant, E. The strengths and weaknesses of written English of Black high school pupils. Per Linguam, 4, 1, 16-23, 1988.

Aron, M.L. Community-based rehabilitation for communication disorders. In W. Smith and S. Meyer (Eds.) SASHA National Con ference Proceedings, Wits: Johannesburg, 1987.

ASHA Social dialects: a position paper. ASHA, 25, 9, 23-24, 1983.

Chick, K. Interactional perspectives on communication needs of Zulu work seekers.Journal of Multilingual and Multicultural Development, 7, 6, 479-492, 1987

Comkowycz, S.M. Ehren, B.J. \& Hayes, N.,H. Meeting classroom needs of language disordered students in middle and junior high school: a program model. Journal of Childhood Communication Disorders, 11, 1, 119-208, 1987.

Damico, J.S. Addressing language concerns in the schools: the SLP as consultant. Journal of Childhood Communication Disorders, 1 1, 1, $17-40,1987$.

Department of Education and Training (DET): DET Annual Report for 1987, RP 65/1988, Pretoria: Government printer, 1988.

Department of National Education: Preliminary Education Statistics for 1988. NATED 02-214 (88/07), Pretoria.

Edwards, J.R. Language and Disadvantage. London: Edward
Arnold, 1979.

Gallagher, T.M. and Prutting, C.A. Pratgmatic assessment and interven tion issues in lancuacue.California: College-Hill press, 1983.

HSRC-Report. The role of language in Black education. Pretoria: HSRC, 1986.

Johanson, L. In search for the common tongue- necessity or dream? Mathlasedi, 7, 1/2, 7-8, 1988.

Kessler, C. Language acquisition in bilingual children. In N. Miller (Ed.) Bilingualism and langmage disability. San Diego: CollegeHill, 1984.

Lewis, R. Memorandum on language-learning deficit in Katlehong Township. Communiphon, Sept/Oct, 285, 20-21, 1988.

Marvin, C. A. Consultation services: Changing roles for the SLP's Journal of Childhood Communication Disorders, 11, 1, 1+15, 1987

Mawasha, A. I. Medium of instruction in Black Education in Southern Africa. HSRC-repert: The Role of Language in Black Education. Pretoria: HSRC, 1986.

Mcdonald, C.A. Primary English school curriculum- on the threshold of radical change. Mathlasedi, 7, 1/2, 18-19,1988.

Odendaal, M.S. Needs analysis of higher primary teachers in Kwazulu. Per Linguam, Special issue, 1985

Reagan, T. The role of language policy in South African Education Language problems and language planning, 10, 1, 1-13, 1986.

Simon, C.S. Out of the broom closet and into the classroom: the emerging SLP. Journal of Childhood Communication Disorders, 11, 1 , $41-66,1987$

Taylor, $\mathrm{O}$. Treatment of communication disorders in culturally and linguistically diverse populations. San Diego: College Hill Press, 1986.

Terrell, S.L. and Terrell, F. Effects of speaking Black English upon employment opportunities. ASHA, 25, 6, 27, 198:3.

Trudgill, P Accent, dialect and the school. Iondon; Edward Arnold, 1987.

Vaughn-Cooke, F.B. The challenge of assessing the language of nonmainstream speakers. In O. Taylor (Ed.) Treatment of com munication disorders in culturally and linguistically diverse populations. San Diego: College Hill, 1986.

Uys, I.C. 'n Mede-konsultasie model vir spraak- en gehoorterapie in die RSA. In I.S. Hay en I.C. Uys (Eds.) Taalverskeidenheid en taalpatologie. Pretoria: Universiteit van Pretoria, 1985.

Westby, C.E. and Rouse, R. Culture in education and the instruction of language learning-disabled students. Topics in Languaste Disorders, 5, 4, 15-28, 1985.

Yoder, D. Some viewpoints of the speech, hearing and language clinician. In F. Williams (Ed.) Language and Poverty. Chicago: Markham, 1970.

\section{CAPE}

P.O.Box 52

Lynedoch

7603

Phone: (024) 512495
NATAL

P.O. Box 47443

Greyville

4023

\author{
SURGICAL \& MEDICAL \\ P.O. Box 19 \\ Bedfordview \\ 2008 \\ South Africa \\ Phone: (011) 53-4188/9
}

\title{
TiChaRds hearing systems
}

Tomorrow's Technology for Today's Hearing Problem 


\section{THIS PAGE IS SPONSORED BY}

\section{THE LITERARY GROUP (PTY) LTD}

\section{ACADEMIC \& MEDICAL BOOKSELLERS}

JOHANNESBURG: CAMPUS BOOKSHOP 34 Bertha Street

2017 Braamfontein

WESTDENE SERVICES 4 Ameshoff Street 2017 Braamfontein

DURBAN: LOGANS WESTDENE 660 Umbilo Road 1400 Durban

CAPE TOWN:
WESTDENE RONDEBOSCH 18 Main Road 7700 Rondebosch
PHONE:

(011) 339-1711

PHONE:

(011) 339-3026

PHONE:

(031) 253221 Ext 22
PHONE:

(021) 689-4112 